\title{
- ЄВРОПЕЙСЬКИЙ КАРНАВАЛ: ТРАДИЦІЇ І СУЧАСНІСТЬ
}

\section{- Курочкін Олександр Володимирович}

- Доктор історичних наук, професор,

ORCID: 0000-0002-3365-7266, e-mail: olexkuro@gmail.com,

Київський національний університет культури і мистецтв,

вул. Є. Коновальця, 36, Київ, Україна, 01133

\section{Для цитування:}

Курочкін, О.В. (2021). Європейський карнавал: традиції і сучасність. Питання культурології, (38), 120-132. doi: https://doi.org/10.31866/2410-1311.38.2021.245789.

\section{- Анотація}

Мета статті - вивчити досвід організації карнавальних розваг як художньо-естетичний феномен та приклад успішної самоорганізації місцевих територіальних громад. У статті розглядаються проблеми функціонування карнавальних традицій у країнах Західної Європи. Методологія дослідження базується на використанні історичного та аналітичного методів, які дозволили прослідкувати європейські карнавальні традиції й визначити роль та місце досліджуваної проблеми у загальному процесі еволюції карнавальної культури. Структурний метод застосовувався в систематизації та викладенні фактичного матеріалу з метою фріксації спільних і відмінних рис народних святкових веселощів. Наукова новизна полягає у тому, що обґрунтовано необхідність розвитку й популяризації карнавальної культури та демократичної святкової комунікації в контексті вітчизняної культури. Висновки. Констатовано, що генетичні предки європейського карнавалу - античні свята діонісій та сатурналій. А масовим народним святом з вуличними процесіями, іграми, театралізованими виставами в масках карнавал став в середні віки завдяки розвитку європейських самоврядних міст й становленню класу буржуазії. Доведено, що головною ідеєю карнавалу є інверсія - зміна вікового, статевого, соціального статусу учасників святкового дійства. Шлях до всебічного пізнання інтернаціонального фонду карнавальних форм лежить через вивчення його національних варіантів. У розвідці простежується генезис й історична трансформація найпопулярніших європейських карнавалів. Європейський карнавал - антипод тоталітарного свята, якому властива надмірна серйозність, фральшива патетика, стереотипний набір ідеологічних гасел і кліше. Досвід організації карнавальних розваг цікавий як приклад демократичної святкової комунікації, яскравий художньо-естетичний френомен, зразок успішної самоорганізації місцевих територіальних громад.

Ключові слова: карнавал; Масляна; свято; традиція; маска; карнавальна інверсія; амбівалентний сміх 


\section{- Вступ}

Карнавал - життєрадісне дитя від шлюбу західноєвропейської цивілізації та католицизму. Основні центри його традиційної пульсації знаходяться в країнах, де сильний вплив римського первосвященника (Італія, Франція, Іспанія, Німеччина, Бельгія, країни Латинської Америки тощо). Генетичні предки карнавалу - античні свята діонісій та сатурналій, під час яких немовби наступав золотий вік - царство загальної рівності та свободи. Пани та слуги мінялися своїми місцями, не бракувало вина та їжі, скасовувалися табу й тріумфували нестримні веселощі.

Колишнє язичницьке аграрне свято проводів зими і зустрічі весни отримало законну прописку в католицькому церковному календарі, де йому відведено місце загального загулу перед Великим постом. Хоча в народній етимології термін карнавал виводять від латинського «Carne Vale» - «прощавай м'ясо», проте більш вірогідно, що він походить від латинського «Carrus navalis» — «потішна колісниця», корабель священних процесій. Саме на таких возах-платфрормах пересувалися у святковому натовпі середньовічні актори, гістріони, блазні-скоморохи, розкидаючи навколо себе непристойні жарти й горох (символ родючості), який пізніше замінили паперові конфретті.

Італійському слову Carneval i французькому Carnaval відповідають німецькі назви Fastnacht i Fasching, англійська Bannoksday, чеські і словацькі Masopust, польська - Zapusty, російська - масленица, українська - масляна.

Масовим народним святом з вуличними процесіями, іграми й театральними виставами в масках карнавал став вже в середні віки завдяки розвитку європейських самоуправних міст й становленню класу буржуазії. У містах з їх «повітрям свободи» цехові ремісники й купці вміли гарно працювати і бучно веселитися. Європейський карнавал - антипод тоталітарного свята, якому властива надмірна серйозність, фральшива патетика, стереотипний набір ідеологічних гасел і кліше. Директивно насаджувана в громадський і сімейний побут офіційна система радянських свят і обрядів була насамперед знаряддям політичної пропаганди і агітації, а тому було вороже ставлення до різних форм і проявів національної своєрідності і розважально-ігрових компонентів святкового дозвілля.

У стані переходу до демократичного суспільства, в якому знаходиться сучасна Україна, корисно вивчити європейський досвід організації масових свят. Йдеться не про механічне перенесення конкретної святкової традиції з одного національного ґрунту на інший, хоча й таке трапляється. Згадаймо, як в нашій країні протягом останніх десятиліть набули популярності такі іноземні святкові бренди, як Хеллоуїн, День Святого Валентина, Октоберфест та ін. Європейський карнавал цікавий нам як приклад демократичної святкової комунікації щодо свободи, як яскравий художньо-мистецький френомен, як зразок успішної самоорганізації окремих територіальних громад.

Теорія карнавалу $є$ полем активних наукових дискусій. Варто розрізняти два основних значення карнавалу - вузьке і широке. За першим стоїть конкретна історична форма масового народного (переважно міського) свята, вмонтованого в релігійний календар народів, які сповідують католицизм. 
Широке розуміння карнавалу як універсального обрядово-видовищного і світоглядного феномена, властивого тією чи іншою мірою усім без винятку цивілізованим народам світу, ще тільки фрормується і в багатьох моментах має попередній, дискусійний характер. Утвердженню його в сучасному гуманітарному дискурсі істотно сприяла новаторська праця М. Бахтіна, присвячена висвітленню народної культури середньовічної Франції. «Карнавал розкриває для нас древню народну святкову стихію як краще збережений уламок цього величезного і багатого світу» (Бахтін, 1990, с. 241). Як представник марксистської науки, М. Бахтін змушений був дослухатись до ідеї В. Леніна про наявність двох класових культур і тому карнавал у нього однозначно $€$ «символом і втіленням справді всенародного свята, цілком незалежного від церкви і держави» (Бахтін, 1990, с. 244).

Наступні покоління дослідників вважали головною вадою цієї концепції різке протиставлення офріційного свята церкви і феодальної держави неофіційній народній святковій культурі. Клерикальну концепцію європейського карнавалу детально обґрунтував профресор етнології німецького університету у Фрайбурзі Дітц Мозер. Наголошуючи на безпосередній залежності карнавалу фреодальної доби від ідеологічних догматів католицизму, він писав: «Звичаї та ігри фастнахту повинні були представляти вірянам перед початком посту життя "за власним бажанням", не за "бажанням Господа", щоб переконливо сприяти їхній готовності до "повороту"» (Moser, 1993, s. 143). Суть цього повороту культуролог бачив в тому, що «пасажири корабля» мають «перейти на корабель святості, церкви» (Moser, 1993, s. 148).

3 поміркованою критикою ідей М. Бахтіна, пов'язаних із середньовічним комізмом і карнавалом, виступили також російські історики-медієвісти (А. Гуревич, В. Даркевич, В. Колязін, М. Реутін). Зокрема, А. Гуревич (1981) визначав концепт М. Бахтіна «імовірніше міфологією карнавалу і сміхової культури, ніж їх дійсною історією» (с. 272).

Зазначаючи уразливі сторони концепції М. Бахтіна, представники міжнародної наукової спільноти визнавали його пріоритет у розкритті компонентної структури народної сміхової культури. Серед головних елементів карнавалу: маски і маскарадні костюми, танці, еротична свобода, надмірності в їжі й питті, інверсія і антиповедінка, критика чинних порядків тощо. Всі ці загальні риси народних святкових веселощів простежуємо і в сучасних формах європейського карнавалу.

\section{- Мета статті}

Мета статті полягає у вивченні досвіду організації карнавальних розваг як художньо-естетичного феномена та успішної самоорганізації місцевих територіальних громад. Методологія дослідження базується на використанні історичного та аналітичного методів, які дозволили прослідкувати європейські карнавальні традиції, визначити значення та місце досліджуваної проблеми у загальному процесі еволюції карнавальної культури. Структурний метод застосовувався в угрупованні та викладенні фактичного матеріалу й спільних рис народних святкових веселощів. Наукова новизна полягає в тому, що обґрунтовано необ- 
хідність розвитку й популяризації карнавальної культури як демократичної святкової комунікації в контексті вітчизняної культури.

\section{- Виклад матеріалу дослідження}

Шлях до всебічного пізнання інтернаціонального фронду карнавальних фрорм лежить через вивчення його національних варіантів. Наприклад, італійців прямих нащадків Давнього Риму - справедливо вважають законодавцями карнавальних традицій. Перед тим як настане сумний період посту, темпераментні жителі півдня зручно використовують нагоду, щоб побенкетувати і повеселитися. За народними віруваннями, пісні, танці, жарти, ігри в масках і фривольна поведінка допомагали прогнати зиму і наблизити весну.

3 двох тисяч карнавалів, які регулярно відбуваються у великих і малих містах Апеннінського півострова, найбільшою популярністю користується венеціанський. Він розквітає кольорами у лютому, коли місто-казка оповите дощами і туманами. Палаци і собори у стилі готики, ренесансу, бароко відбиті у водах численних каналів, впродовж десяти днів слугують розкішними декораціями грандіозного свята. Щоб взяти в ньому участь, сюди нерідко прибуває близько 100 тис. гостей із багатьох країн світу.

Цікава його історія. Він нібито був започаткований у XI ст. на згадку про звільнення викрадених далматинськими піратами венеціанських дівчат-наречених. Відтворюючи старовинну легенду, сьогодні перед глядачами постають сім красунь - сім Марій, яких обирають на конкурсних засадах. Середньовічний карнавал був не лише веселим, але й кровожерним. Аж до XVII ст. на площі Святого Марка у присутності дожа собаками цькували дванадцять свиней і одного бика. Пізніше ці варварські забави були скасовані.

Перша письмова згадка про бучні венеціанські свята, що передували посту, припадає на 1268 р., коли гультяям у масках заборонили кидатися яйцями з вікон (Гаррет, 2007 , с. 270). Це була не остання спроба надати карнавальним звичаям позірної благопристойності.

Карнавальну публіку зазвичай розважали акробати і фокусники, танцюючі собаки, мавпочки і лялькові вистави. Візитівкою свята і його урочистим початком був volo del Turko (політ турка): вправний акробат здіймався канатом на маківку собору Сан-Марко, спускався наниз другим канатом, щоб піднести дожу букет квітів і хвалебний вірш, потім знову підіймався нагору й спускався на корабель, який стояв поблизу.

Характерними постатями карнавалу були ворожки. За розповіддю мандрівника XVII ст. Франсуа Міссьона, «у цих віщих ворожок є довга бляшана труба, через котру вони говорять прямо у вухо цікавим, які стоять внизу біля помосту». На подив Ф. Міссьона, священники і монахи особливо часто «радилися з трубою» (Гаррет, 2007, с. 271).

Свого найвищого розквіту карнавал у Венеції досяг у XVIII ст. 3 усієї Європи сюди прибували аристократи, багачі, шукаючи пригод (не раз тут бував, до речі, невтомний коханець Джакомо Казанова), щоб насолоджуватись музикою, театром, та іншими, не менш приємними радощами життя. Підкоряючись смакам епохи, карнавал поступово трансформувався на «галантне свято», де панувала 
атмосфера грайливого лукавства, брутальних пустощів і амурних витівок. У численних затишних місцях, ховаючись під покровом масок, венеціанські патриції й буржуа зраджували своїм дружинам, які також знаходили втіху на стороні. Не піддатися плотським спокусам напередодні посту, коли навіть церква дивилася на ці гріхи крізь пальці, було неможливо. Звичайно, і тоді траплялися ревниві чоловіки та уражені суперники. Конфлікти залагоджувалися легко за допомогою шпаги на дуелях - навіть смерть під час карнавалу вважалася почесною.

Венеціанський карнавал втратив свою привабливість і занепав після того, як італійські землі загарбала Австро-Угорська монархія. Волелюбні громадяни колишньої «володарки морів» не вважали можливим бучно веселитися в умовах чужоземної окупації. Американський консул у Венеції з 1861 р. так схарактеризував вбогу пародію колишнього свята: «...група жебраків, які начепили маски, роги і жіночу одежу. У такому вигляді жахлива процесія чвалає від крамниці до крамниці, гугнявлячи блазнівські пісні і збираючи у крамарів данину» (Гаррет, 2007, с. 273).

По-справжньому відродити карнавал вдалося лише у 1980 р. зусиллями театрального режисера з Рима Мауріціо Скапарро. Спочатку його реконструювали з метою залучення туристів у міжсезонний період, але скоро свято переросло місцеві масштаби і перетворилося на одну з найяскравіших подій у культурному житті всієї планети. Венеціанський карнавал сьогодні - це і модний захід представників богеми, і місце зустрічі романтичних закоханих, і туристична Мекка, і екзотичне дозвілля заможних людей... і феєричний спектакль, що відбувається просто неба й у розкішних патриціанських віллах.

Прологом свята є символічна церемонія, що повторюється з року в рік, як колись «політ турка»: із дзвіниці собору Сан-Марко злітає прив'язана тонкою ниткою паперова голубка - Коломбіна. У повітрі вона вибухає, обсипаючи багатотисячний натовп на площі барвистим дощем із конфетті. Після цього починається багатоденний карнавал - «хеппенінг», який складається з численних акцій, що відбуваються на центральній площі міста Сан-Марко і на маленьких площах: концертів, театральних вистав, танців, процесій, конкурсів, ігор, феєрверків тощо. Артисти та більшість глядачів у масках і карнавальних костюмах. Їх тисячі: різні типажі, назви, манери. Лише досвідчене око спеціаліста здатне розпізнати серед них певні історичні нашарування й стилі.

Карнавальні маски живуть за законами людських пристрастей. Ось характерні образи славнозвісної італійської комедії дель арте: вже кілька століть поспіль неначебто наївний простак Арлекін виходить переможцем з усіх життєвих ситуацій; Панталоне - карикатурний тип венеціанського купця, символ скупого дурня; розпусний і потворний Пульчинелла - близький родич французького Полішинеля й російського Петрушки; П'єро, який втілює засліпленого пристрастю чи то чоловіка, чи то коханця, котрого спритно обманює чарівна і легковажна Коломбіна.

До давніх венеціанських личин належить знаменита «Баута» - таємнича біла півмаска, нерідко облямована чорною бородою. Вона надавала страхітливого вигляду, тому її любили мафріозі XVII-XVIII ст. Дуже виразний і образ Чумного лікаря - фантастичної фрігури у чорному плащі й масці з довгим «дзьобом». 
За легендою в таких масках обходили зачумлені квартали середньовічні лікарі - суміш трав, покладена до «дзьоба», захищала їх від зараження. Для карнавальних флліртів і любовних інтриг часто використовувалися маски «Маттачино» і «Моретто», що закривали повністю обличчя, залишаючи лише вузькі щілини для очей.

3 історичними масками легко переплутати франтастичні, створені сучасними художниками й модельєрами. Мають успіх маски діснеївських персонажів і героїв дитячих мультфільмів. У місцевих салонах і магазинах їх безліч і на всі смаки.

Добре відчути радість карнавальних перетворень, загубившись у веселому натовпі на площах давнього міста. Але найвишуканіше видовище - балимаскаради, що відбуваються в аристократичних палацах. Відомих осіб сюди запрошують, а звичайним людям доводиться купувати квиток, вартість якого близько 300 доларів. У старовинних інтер'єрах палаців, де влаштовують бали для ексклюзивної публіки, годиться бути у відповідних історичних костюмах. Їх можна узяти напрокат, заплативши 50-100 доларів, або замовити заздалегідь у спеціальних майстернях. Подейкують, що ціна цих виробів не буває менше ніж 10 тис. доларів, але охочих зробити собі такий подарунок завжди вистачає.

Венеціанський карнавал нині все більше орієнтується на комерцію й широке залучення туристів - організатори кожного року вигадують різноманітні рекламні трюки й провокації задля приваблення публіки.

3 меншим розмахом, але також весело прощаються з зимою у невеликих містах і містечках Італії. Головний епізод цього свята - традиційна «кривава» битва між товстуном Карнавалом і худокостою бабою Кваризимою, яка уособлює сорокаденний Великий піст перед Великоднем. Ці ролі виконують ряджені актори або ляльки. Кваризима завжди перемагає, а Карнавал спалюють або топлять у річці. Ця смерть не страшна, тому що італійці знають — карнавал з усіма його радощами обов'язково повернеться наступного року.

У німецьких середньовічних джерелах неодноразово згадувався масляничний карнавал або Fasching, який вже у XIX ст., за словами історика М. Реутіна (1996), «перетворився в одну з форм міського дозвілля, тому він цілком сумісний якщо не в етичному, то принаймні в психологічному відношенні - 3 католицизмом і церковною доктриною» (с. 114).

Найміцнішою цитаделлю німецького карнавалу вважають Кельн, Дюссельдорф, Майнц, Бонн. Місцеві жителі, як встановили дослідники, віддані цій «гріховній» традиції вже впродовж восьми століть. За визначенням Йоганна Вольфганга фон Гете: «Карнавал - це свято, яке не дають народу, а таке, що належить самому народу» (цит. за: Oelsner, 2007, s. 17).

Організацією карнавалів у добропорядній Німеччині займаються спеціальні товариства, члени яких, згідно з регламентом, мають свої парадні костюми, особливі знаки розрізнення та нагороди. Перше таке товариство було засноване у Кельні ще у 1832 р. Сьогодні у місті діє вже понад сотня карнавальних товариств або комітетів. Члени цих громадських об'єднань хизуються неповторними головними уборами, за якими легко впізнають одне одного. Засідання карнавальних стратегів відбуваються переважно у залах клубів і ресторанів, за столами, уставленими вином і пивом. Зазвичай вони розпочинаються об 11 го- 
дині 11 хвилин 11 числа 11 місяця, тобто 11 листопада, в день Святого Мартіна. До речі, у німців 11 - «блазнівське» число, тоді як у нас воно означає пересування пішки (на двох ногах). На засіданнях товариств обирають карнавальне керівництво: короля або принца карнавалу, а також принцесу, колегію дурнів і ораторів.

«П'ята пора року», як називають німці карнавал, настає за шість днів до Великоднього посту, коли жителі міста під залпи потішної артилерії, що стріляє карамеллю і конфетті, захоплюють ратушу, виганяють бургомістра з усім його чиновницьким почтом і беруть владу до своїх рук, перевертаючи усталені порядки догори дриґом. Від цієї миті дозволені всілякі дурниці й витівки. Солідні бюргери та батьки сімейств перетворюються на хлопчиків-шибеників, відчайдушних ловеласів. Залишатися тверезим і розсудливим у цій спільноті рівнозначно самогубству. Розперізуються і педантичні німецькі жінки. Забувши свої традиційні «три К» - Kirche, Kuche, Kinder (церкву, кухню, дітей), вони буквально полюють на представників сильної статі, щоб, користуючись карнавальним привілеєм, відрізати у них краватку чи отримати кілька марок (а тепер вже - євро) на почастування. Фрау потім хизуються маскарадними спідничками з обрізків чоловічих краваток.

Кульмінація карнавалу припадає на неділю, понеділок і вівторок перед «попільною середою». У Кельні та деяких інших містах особливо відзначається «трояндовий понеділок» (Rosenmontag). Саме цього дня містом проходить грандіозна процесія пишно декорованих машин, платформ, возів у вигляді символічних корабликів, груп ряджених пішоходів і вершників.

Святкову ходу можна спостерігати майже в кожному куточку міста - такий звивистий її шлях. Але особливе скупчення публіки в центрі біля 174-метрової громади Кельнського собору. Карнавальний парад, як і все у німців, розгортається за визначеним сценарієм і $є$, по суті, багатоактним рухомим спектаклем. Кожна колона, платформа розкриває певну тему. Згідно з ритуалом, процесію танцюристів очолює Арлекін, за ним ідуть одягнені в колоритні костюми «святі слуги та служниці» — колись їх зображували 11 молодих шлюбних пар, що мали добру репутацію і яким місто забезпечувало благодійне придане.

Серед обов'язкових масок карнавалу у Кельні - відома алегорична трійця: принц, селянин і непорочна діва. Роль незайманої завжди виконує чоловік. Селянин, який помахує туди-сюди молотильним ціпом, символізує стійкість і бойовий дух «старого імперського міста Кельна», а принц - не лише блискучий герой-лицар, але й синонім Масляної - азартний гульвіса. Поруч із цими історичними фігурами часто можна бачити ряджених у костюмах клоунів, що складаються з сотень, а то й тисяч окремих клаптиків матерії, з'єднаних в одне ціле майстерними швами. Це мало уособлювати гріховність людської натури.

Від сили-силенної масок рябіє в очах. Чим безглуздіший карнавальний костюм, тим більший успіх. Зустрічаються дуже дорогі карнавальні костюми, що відтворюють у деталях «ношу» всіх епох і народів, а трапляються експромти, «зліплені» швидкоруч. Кожен виявляє себе як хоче і ніхто нікому не заважає.

Спливає година, друга, третя, а ході немає кінця. Нові оркестри, нові герої, нові театралізовані сценки й розіграші. Натовп підхоплює знайомі мелодії, і все 
місто стає різноголосим, але дуже натхненним хором. Спектакль приносить задоволення і глядачам, і артистам. Останні, на радість дітей, щедро розкидають цукерки, шоколад, печиво і квіти. Підраховано, наприклад, що під час традиційної ходи в «трояндовий понеділок» 2001 р. карнавальні колективи Кельна пожбурили в натовп 300 тис. букетів квітів, 220 тис. коробок цукерок, 70 тис. плиток шоколаду і (лише вдумайтесь) 140 тонн цукерок розсипом. Прикметно, що все подарункове багатство купується за гроші учасників карнавалу і розкидається просто так, заради взаємного задоволення.

Лише ввечері натовпи ряджених з вулиць і площ розтікаються по численних ресторанах, кафе і кнайпах, що заздалегідь «бронюються» для проведення карнавальних балів. Члени блазнівських комітетів і корпорацій із почуттям виконаного обов'язку розпочинають бенкет. Мимоволі здається, що учасники цих бучних бенкетів намагаються відтворити сцени «гастрономічних подвигів» велетня Пантагрюеля з відомого гротескового роману XV ст. Франсуа Рабле.

На відміну від інших країн, де живуть традиції карнавалу, рейнський карнавал дуже рано набув політичного забарвлення і перетворився на своєрідну платформу змагань політичних партій. Засвітитися з влучним тостом чи дотепним спічем під час масляничного застілля - чудовий шанс запропонувати себе у депутати місцевого ландтагу. Тому заздалегідь готуються гумористичні промови, замовляються злободенні куплети, пісні та епіграми. За старою кельнською традицією, оратори озвучують їх у спеціальних діжках, у яких колись місцеві прачки полоскали брудну білизну. Натяк цілком прозорий: політика, як відомо, справа надзвичайно брудна.

До кельнського карнавалу подібні й інші німецькі карнавали. Чим більше місто, тим помпезніше свято. Процесії у маленьких містах не такі грандіозні, тут скромніші костюми й менші оркестри, але атмосфера загального безумства і радості та сама. Цікаво, що німецький карнавал свого часу справив велике враження на майбутнього «вождя світового пролетаріату» В. Леніна. У листі до матері з Мюнхена він писав 20(7) лютого 1901 р.: «Днями скінчився тут карнавал. Я перший раз бачив останній день карнавалу за кордоном - процесія ряджених на вулиці. Загальні пустощі, хмари конфетті, яке кидають в обличчя, паперові змійки тощо. Вміють тут публічно на вулиці веселитися» (цит. за: Филимонова, 1977, с. 145).

Свої неповторні прикмети мають масляничні карнавали у невеликих німецьких містах - у Юберлінгені, Констанці та інших на Боденському озері. На свята тут заведено виконувати старовинні народні танці, зокрема танці з мечами. Право виконувати ці танці, як вважають самі юберлінгенці, було надане їм кайзером за особливі заслуги у війнах. Танцюристи зазвичай проходять під схрещеними мечами і переплигують через мечі. Виконуються на карнавалі й середньовічні танці ремісників з обручами (танці бондарів), ковалів, м'ясників та ін. (Филимонова, 1977, с. 145).

У бельгійському (валлонському) місті Бенш (провінція Ено), де є власний музей масок, простежуємо тісний зв'язок карнавалу з католицизмом. Згідно з легендою, карнавал справляли в Бенші ще у 1594 р., але найдавніша згадка про цю подію в архівах міста датується 1795 р. (Решина, 1977, с. 71). 
Цікаво, що місцеве карнавальне товариство виробило статут про збереження фольклору й правила проведення масляничного свята, де все регламентовано. За цим статутом у Бенші домінує одна карнавальна маска - образ Жиля (gill - блазень, клоун). Його костюм був уніфікований і став традиційним. Звичайно костюм цей горохового кольору, орнаментований чорними і червоними левами; на поясі у кожного Жиля дзвіночки, а на ногах важкі дерев'яні черевики - сабо. Характерний атрибут спорядження карнаваліста - горб, набитий соломою, прикритий мереживним коміром, закріпленим на грудях білим бантом (Решина, 1977, с. 72). Однотипні й маски на обличчі Жилів. Вони мають характерні бакенбарди і довгі вуса за еталоном моди часів французького імператора Наполеона III. Існує гіпотеза, що сучасна маска - образ Жиля замінила більш давній костюм класичного Арлекіна з італійської комедії дель арте. I лише в Бенші можна побачити, як карнавальний персонаж протягом одного дня проходить різні вікові стадії: Жиль починає ранок юнаком, вдень досягає найбільшого розвитку, а увечері старіє. Так маски наочно демонструють плинність людського буття.

Карнавальне дійство у місті Бенш, де протягом трьох днів публіку розважають близько тисячі елегантних Жилів, приваблює багатьох туристів. Місцева громада виступає гарантом додержання канону й естетичної довершеності традиційних масок.

3 традиційними карнавалами, що мають глибоку традицію, сьогодні конкурують нові, вже не прив'язані до церковного календаря. Найвідоміший серед них музичний карнавал, який влітку відбувається у престижному лондонському передмісті Ноттінгем-Хілл. Це найбільша «тусовка» Старого світу, що збирає до двох мільйонів гостей.

Своїм народженням карнавал зобов'язаний афрриканським вихідцям з колишніх колоніальних територій Великої Британії. Чималу групу серед них складали мігранти з колишньої Вест-Індії та островів Карибського моря. Все починалося з ностальгічного бажання кількох карибських емігрантів потанцювати на вулиці під мелодії далекої батьківщини. За музичний супровід використовувалися так звані сталеві барабани, а насправді каструлі, баки і банки, оскільки по ним зручно відбивати дерев'яними паличками запальні латиноамериканські та афроамериканські ритми. Так формувався музичний напрям Calipsomusik, без якого не обходиться тепер жодне карнавальне дійство.

Кожен, хто потрапляє у вир свята в Ноттінгем-Хілл, має бути готовим до того, що темпераментні латиноамериканці й африканці в ексцентричному вбранні насильно затягнуть у свої еротично-шаманські танці, після чого ваш одяг буде нагадувати плямистий комбінезон маляра. Але карнавал можна спостерігати і збоку, сидячи в одному з численних ресторанів і пабів на відкритій терасі. Космополітична джазова какофонія чудово сполучається з величезним вибором страв і напоїв, що презентують кухню багатьох народів світу.

\section{- Висновки}

Отже, сучасні карнавали - явище складне і неоднозначне. За цим загальним поняттям криється значна кількість місцевих свят різного походження, але 
таких, що мають певні спільні риси народних святкових веселощів. Позбавившись релігійної опіки, карнавал став важливим індикатором демократичного суспільства, де організаторами свята виступають ні держава, ні церква, а самодіяльні творчі об'єднання самих громадян.

Розглянуті у розвідці карнавали, здобувши славу традиційних, міцно увійшли в святковий календар Західної Європи. Сьогоденний карнавал яскраво демонструє прагнення людей бути не лише споживачами естетичної продукції, а й суб'єктами творчого процесу і переживання. Це свято покликано розважати і зближувати людей, даруючи їм миттєвості щастя і відпочинку.

Карнавальний рух переживає справжній бум. ${ }^{1}$ Його осередки з'являються сьогодні в Великій Британії, Японії, Фінляндії, Польщі, Болгарії тощо. Ідея організації спеціалізованих фестивалів карнавального мистецтва нині знаходить позитивний відгук і в країнах Східної Європи. Сприятливі умови для розвитку й популяризації вітчизняної карнавальної культури мають західні області України, де ще побутують живі вогнища святкового рядження і маскування, пов'язані з різдвяним вертепом і традиційними новорічними обходами типу «Меланка» або «Маланка».

\section{Список використаних джерел}

Бахтин, М. (1990). Творчество Франсуа Рабле и народная культура средневековья и Ренессанса. Художественная литература.

Гарретт, М. (2007). Венеция. История города. Эксмо; Мидгард.

Гуревич, А. Я. (1981). Проблемы средневековой народной культуры. Искусство.

Курочкін, О. (2014). Святковий рік українців від давнини до сучасності. Видавець Пшонківський О. В.

Реутин, М. Ю. (1996). Народная культура Германии. Российский государственный гуманитарный университет. Институт высших гуманитарных исследований.

Решина, М. И. (1977). Народы Бельгии и Нидерландов. В С. А. Токарев, И. Н. Гроздова, Ю. В. Иванова, \& В.К. Соколова (Ред.), Календарные обычаи и обряды в странах Зарубежной Европы. XIX-начало XX в. Весенние праздники (с. 70-87). Наука.

Филимонова, Т. Д. (1977). Немцы. В С. А. Токарев, И.Н.Гроздова, Ю. В. Иванова, \& В. К. Соколова (Ред.), Календарные обычаи и обряды в странах Зарубежной Европы. XIX - начало XX в. Весенние праздники (с. 139-162). Наука.

Moser, D.-R. (1993). Brauch und Feste im christlichen Jahreslauf. Styria.

Oelsner, W. (2007). Karneval — Wie geht das? Bachem-Verlag.

\section{- References}

Bakhtin, M. (1990). Tvorchestvo Fransua Rable i narodnaya kul'tura srednevekov'ya i Renessansa [Francois Rabelais' Creativity and Folk Culture of the Middle Ages and Renaissance]. Khudozhestvennaya literatura [in Russian].

Filimonova, T. D. (1977). Nemtsy [Germans]. In S. A. Tokarev, I. N. Grozdova, Yu. V. Ivanova, \& V. K. Sokolova (Eds.), Kalendarnye obychai $i$ obryady $v$ stranakh Zarubezhnoy

1 Йдеться про часи до епідемії коронавірусу COVID-19. 
Evropy. XIX - nachalo XX v. Vesennie prazdniki [Calendar customs and ceremonies in the countries of Foreign Europe. The $19^{\text {th }}$ - early $20^{\text {th }}$ century. Spring Holidays] (pp. 139-162). Nauka [in Russian].

Garrett, M. (2007). Venetsiya. Istoriya goroda [Venice. History of the City]. Eksmo; Midgard [in Russian].

Gurevich, A. Ya. (1981). Problemy srednevekovoy narodnoy kul'tury [Problems of medieval folk culture]. Iskusstvo [in Russian].

Kurochkin, O. (2014). Sviatkovyi rik ukraintsiv vid davnyny do suchasnosti [Festive year of Ukrainians from ancient times to the present]. Vydavets Pshonkivskyi O. V. [in Ukrainian].

Moser, D.-R. (1993). Brauch und Feste im christlichen Jahreslauf [Customs and festivals in the Christian course of the year]. Styria [in German].

Oelsner, W. (2007). Karneval - Wie geht das? [Carnival - how does it work?]. BachemVerlag [in German].

Reshina, M. I. (1977). Narody Bel'gii i Niderlandov [Peoples of Belgium and the Netherlands]. In S. A. Tokarev, I. N. Grozdova, Yu. V. Ivanova, \& V. K. Sokolova (Eds.), Kalendarnye obychai i obryady v stranakh Zarubezhnoy Evropy. XIX - nachalo XX v. Vesennie prazdniki [Calendar customs and ceremonies in the countries of Foreign Europe. The $19^{\text {th }}$ - early $20^{\text {th }}$ century. Spring Holidays] (pp. 70-87). Nauka [in Russian].

Reutin, M. Yu. (1996). Narodnaya kul'tura Germanii [Folk Culture of Germany]. Rossiyskiy gosudarstvennyy gumanitarnyy universitet, Institut vysshikh gumanitarnykh issledovaniy [in Russian].

\section{- EUROPEAN CARNIVAL: TRADITIONS AND MODERNITY}

\section{Oleksandr Kurochkin}

- DSc in History, Professor, ORCID: 0000-0002-3365-7266, e-mail: olexkuro@gmail.com, Kyiv National University of Culture and Arts, Kyiv, Ukraine

\section{Abstract}

The purpose of the article is to consider the experience of carnival entertainment arrangement as an artistic and aesthetic phenomenon and an example of successful self-organisation of local communities. The research methodology is based on historical and analytical methods that allowed us to trace the European carnival traditions and determine the role and place of the studied problem in the general process of evolution of carnival culture. The structural method was used in the fact systematisation and presentation to document folk holiday entertainment's common and distinctive features. The scientific novelty is that national culture requires developing and popularising carnival culture and democratic festive communication. Conclusions. The article states that the genetic ancestors of the European carnival are the Dionysius and Saturnalia ancient holidays. And the carnival became a mass folk holiday with street processions, games, theatrical performances in masks in the Middle Ages due to the development of self-governing 
European cities and the formation of the bourgeois class. The author has proved that the main idea of the carnival is an inversion - to change the age, gender, social status of the participants of the festive event. The way to a comprehensive knowledge of the international fund of carnival forms lies through studying its national variants. There is the genesis and historical transformation of the most popular European carnivals in the research. The European Carnival is the antithesis of a totalitarian holiday characterised by excessive seriousness, false pathos, and a stereotypical set of ideological slogans and clichés. The experience of carnival entertainment arrangement is interesting as an example of democratic festive communication, a bright artistic and aesthetic phenomenon, and successful self-organisation of local communities.

Keywords: carnival; Masnytsia; holiday; tradition; mask; carnival inversion; ambivalent laughter

\section{- ЕВРОПЕЙСКИЙ КАРНАВАЛ: ТРАДИЦИИ И СОВРЕМЕННОСТЬ}

\section{Курочкин Александр Владимирович}

- Доктор исторических наук, профрессор, ORCID: 0000-0002-3365-7266, e-mail: olexkuro@gmail.com, Киевский национальный университет культуры и искусств, Киев, Украина

\section{Аннотация}

Цель статьи - изучить опыт организации карнавальных развлечений как художественно-эстетический феномен и пример успешной самоорганизации местных территориальных общин. В статье рассматриваются проблемы фрункционирования карнавальных традиций в странах Западной Европы. Методология исследования базируется на использовании исторического и аналитического методов, которые позволили проследить европейские карнавальные традиции и определить роль и место исследуемой проблемы в общем процессе эволюции карнавальной культуры. Структурный метод применялся в систематизации и изложении фактического материала с целью фиксации общих и отличительных черт народного праздничного веселья. Научная новизна заключается в том, что обоснована необходимость развития и популяризации карнавальной культуры и демократической праздничной коммуникации в контексте отечественной культуры. Выводы. Констатировано, что генетические предки европейского карнавала античные праздники дионисий и сатурналий. А массовым народным празднеством с уличными процессиями, играми, театрализованными представлениями в масках карнавал стал в Средние века вследствие развития европейских самоуправляющихся городов и становления класса буржуазии. Доказано, что главной идеей карнавала является инверсия - изменение возрастного, полового, социального статуса участников праздничного действа. Путь к всестороннему познанию интернационального фонда карнавальных форм лежит через изучение его национальных вариантов. Исходя из этого, в исследовании прослеживается генезис и историческая трансформация наиболее популярных европейских карнавалов. Европейский карнавал - антипод тоталитарного 
праздника, которому свойственна чрезмерная серьезность, фральшивая патетика, стереотипный набор идеологических лозунгов и клише. Опыт организации карнавальных развлечений интересен как пример демократической праздничной коммуникации, яркий художественно-эстетический френомен, образец успешной самоорганизации местных территориальных общин.

Ключевые слова: карнавал; Масленица; праздник, традиция; маска; карнавальная инверсия; амбивалентный смех 